\title{
Spuścizny konserwatorów zbiorów, kierowników i dyrektorów Biblioteki Poznańskiego Towarzystwa Przyjaciół Nauk
}

\begin{abstract}
Streszczenie. Artykuł prezentuje sylwetki konserwatorów zbiorów, kierowników i dyrektorów Biblioteki Poznańskiego Towarzystwa Przyjaciół Nauk (PTPN) oraz to, co po nich pozostało w postaci archiwaliów. Od momentu powstania Biblioteka PTPN gromadziła rękopisy lub całe spuścizny wybitnych osób, w tym kierujących tą placówką. Również inne biblioteki i archiwa zakładowe instytucji, z którymi byli oni związani, włączały do swych zbiorów ich materiały archiwalne. Spuścizny Ludwiki Dobrzyńskiej-Rybickiej i Ryszarda Marciniaka znajdują się zarówno w Bibliotece PTPN, jak i w Polskiej Akademii Nauk Archiwum w Warszawie Oddział w Poznaniu. Znaczna część materiałów archiwalnych Bolesława Erzepkiego trafiła natomiast do Działu Zbiorów Specjalnych Biblioteki Raczyńskich w Poznaniu. Szczątkowe materiały archiwalne można też znaleźć w Archiwum Uniwersytetu im. Adama Mickiewicza w Poznaniu (Ludwika Dobrzyńska-Rybicka) oraz w Archiwum Biblioteki Uniwersyteckiej w Poznaniu (Ludwika Dobrzyńska-Rybicka, Jan Baumgart, Aniela Koehlerówna).
\end{abstract}

SŁowA KLuczowe: spuścizna, biblioteka, archiwum.

\section{Pierwsi konserwatorzy zbiorów}

Biblioteka Poznańskiego Towarzystwa Przyjaciół Nauk (PTPN) powstała razem z towarzystwem w 1857 roku. Ówczesne Towarzystwo Przyjaciół Nauk (TPN) w Poznaniu od początku stawiało sobie za cel między innymi gromadzenie zbiorów i pamiątek, a biblioteka miała być warsztatem pracy poznańskich uczonych i strażnicą dóbr narodowych. Od momentu powstania biblioteka wzbogacała swe zbiory przez dary, wymianę i zakup. Towarzystwo, nie przewidując szybkiego wzrostu księgozbioru, 
w pierwszym statucie pominęło stanowisko bibliotekarza. Pierwotnie całością zbiorów miała się opiekować jedna osoba, pełniąca funkcje zarówno sekretarza, jak i konserwatora zbiorów. Na te zbiory składały się wówczas: działy archeologiczny, numizmatyczny, przyrodniczy, galeria malarstwa, muzeum pamiątek historycznych, archiwalia i biblioteka. W 1880 roku Zarząd TPN rozdzielił stanowiska sekretarza i konserwatora zbiorów oraz dodał temu ostatniemu do pomocy bibliotekarza ${ }^{1}$. W pierwszych latach istnienia towarzystwa powstał zbiór rękopisów, gdyż ich gromadzenie uważało ono za swój statutowy obowiązek. W 1895 roku zbiór rękopisów został wyodrębniony z reszty zbiorów i otrzymał odrębne pomieszczenie. Przechowywane są w nim między innymi spuścizny konserwatorów zbiorów, kierowników i dyrektorów Biblioteki PTPN.

Pierwszym konserwatorem zbiorów był Antoni Rose (1859), drugim Emil Kierski (1859). W listopadzie 1859 roku stanowisko to objął Albin Górecki, od 1861 roku członek Zarządu TPN w Poznaniu. Opracował on część zbiorów biblioteki oraz spisał pierwszy ich katalog. Zapoczątkował też wymianę wydawnictw własnych towarzystwa $\mathrm{z}$ ośrodkami zagranicznymi. Na skutek choroby ustąpił z zajmowanego stanowiska, które 7 marca 1866 roku objął (pracując dorywczo) sekretarz Wydziału Historyczno-Literackiego TPN w Poznaniu Władysław Wierzbiński².

Po Władysławie Wierzbińskim, od 1 kwietnia 1868 roku, na stanowisku konserwatora zbiorów pracował Hieronim Feldmanowski (7 września 1822 - 11 lipca 1885), który równocześnie został sekretarzem towarzystwa i wszedł do jego Zarządu. Jako konserwator sporządził spis książek oraz zbiorów muzealnych i archeologicznych towarzystwa. W 1869 roku ogłosił Katalog Biblioteki Tow. Przyjaciót Nauk Poznańskiego w układzie systematycznym, a w 1872 roku Katalog duplikatów z Biblioteki Tow. Przyjaciót Nauk, u bibliotekarza Towarzystwa (w języku polskim i niemieckim). Za jego czasów znacznie powiększył się księgozbiór, głównie dzięki darom. Pod koniec 1881 roku, w związku z krytyką jego działalności, zrezygnował z zajmowanego stanowiska, które objął po nim Klemens Kantecki. Feldmanowski nadal był jednak pomocniczo zatrudniony przy opracowaniu zbiorów, a od kwietnia 1883 roku zastępował chorego Kanteckiego. Po zrzeczeniu się przez Kanteckiego stanowiska Feldmanowski pełnił tymczasowo obowiązki konserwatora aż do śmierci, zapoznając jednocześnie z pracą swego następcę - Bolesława

${ }^{1}$ A. Koehlerówna, Biblioteka Poznańskiego Towarzystwa Przyjaciót Nauk 1857-1957, „Roczniki Historyczne” 1957, s. 381-402.

${ }^{2}$ W. Pawlikowski, Górecki Albin, w: Słownik pracowników książi polskiej, Warszawa-Łódź 1972, s. 234. 
Erzepkiego ${ }^{3}$. W zbiorze rękopisów Biblioteki PTPN zachowała się korespondencja wpływająca Feldmanowskiego z lat 1867-1884 (w języku polskim, niemieckim i włoskim), zakupiona w 1965 roku od Teresy Tuliszkowej (rkp. 833), oraz tekst Galerya obrazów zbioru [Edwarda] Rastawieckiego spisat $i$ opisat H[ieronim] Feldmanowski i życiorysy autorów dodat (rkp. 1202)4.

1 kwietnia 1882 roku stanowisko konserwatora zbiorów objął Piotr Klemens Kantecki (19 maja 1851 - 14 października 1885). Podczas jego urzędowania, 8 listopada 1882 roku, nastąpiło otwarcie czytelni i zbiorów muzealnych w nowym gmachu przy ul. Młyńskiej 35 w Poznaniu. Kantecki uporządkował i skatalogował bibliotekę. Wzorując się na Zakładzie Narodowym im. Ossolińskich we Lwowie, w którym w latach 1876-1882 był skryptorem, zaprowadził katalog kartkowy oraz zmienił dotychczasowy układ księgozbioru według rodzajów piśmiennictwa na układ sygnaturowy (tzw. numerus currens) z uwzględnieniem trzech formatów. W listopadzie 1882 roku ogłosił drukiem Dublety Biblioteki Tow. Przyjaciół Nauk. Czasopisma, a w 1883 roku Katalog duplikatów z Biblioteki Tow. Przyjaciót Nauk, które nabywać można $u$... w Роznaniu. Opracował też regulamin dla osób korzystających z biblioteki i włączył do jej księgozbioru liczne dary ${ }^{5}$. W zbiorze rękopisów Biblioteki PTPN zachowała się Księga darów bibliotecznych i muzealnych, prowadzona przez niego od 8 stycznia do 2 lipca 1885 roku (rkp. 1203), oraz wspomniany Katalog duplikatów z Biblioteki Towarzystwa Przyjaciół Nauk, które nabywać można u Konserwatora Zbiorów Towarzystwa Klemensa Kanteckiego w Poznaniu (ul. Młyńska 35), wydany w Poznaniu w 1883 roku (rkp. 1405) ${ }^{6}$.

\section{Bolesław Erzepki*}

1 lipca 1885 roku zastępcą konserwatora zbiorów TPN w Poznaniu został mianowany Bolesław Erzepki. Wkrótce potem zmarł Hieronim

* Fotografia Ludwiki Dobrzyńskiej-Rybickiej pochodzi ze zbiorów PAN Archiwum w Warszawie Oddział w Poznaniu, pozostałe fotografie pochodzą ze zbiorów Biblioteki PTPN.

${ }^{3}$ Z. Grot, Feldmanowski Hieronim, w: Polski słownik biograficzny, t. 6, Wrocław 1948, s. 404; A. Koehlerówna, op.cit., s. 404-405; W. Pawlikowski, Feldmanowski Hieronim, w: Słownik pracowników książki polskiej, s. 216.

4 Inwentarz rękopisów Biblioteki Poznańskiego Towarzystwa Przyjaciół Nauk (sygn. 1-1950), oprac. B. Olejniczak, J. Pietrowicz, Warszawa 2008, s. 146, 300.

${ }^{5}$ A. Koehlerówna, op.cit., s. 405-406; M. Wojciechowska, Kantecki Piotr Klemens, w: Polski słownik biograficzny, t. 11, Wrocław 1964-1965, s. 616-618; E. Szczawińska, Kantecki Piotr Klemens, w: Słownik pracowników książi polskiej, s. 392.

${ }^{6}$ Inwentarz rękopisów Biblioteki..., s. 301, 411. 


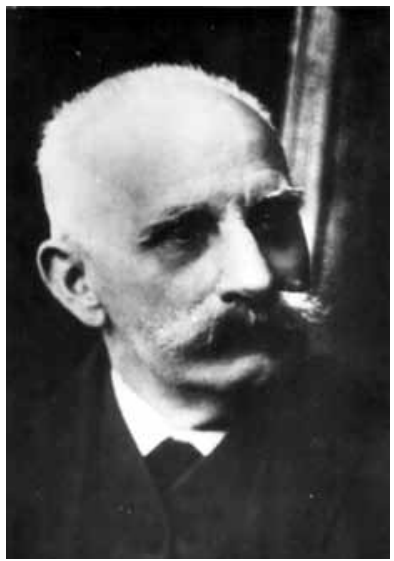

Feldmanowski, pełniący obowiązki konserwatora zbiorów. Od 1 stycznia 1886 roku aż do przejścia na emeryturę w 1919 roku Bolesław Erzepki piastował stanowisko konserwatora zbiorów. Urodził się 5 lipca 1852 roku w Pawłowicach koło Leszna. Od 1875 roku studiował filologię słowiańską i historię na Uniwersytecie Wrocławskim, a w 1885 roku otrzymał stopień doktora filozofii na podstawie rozprawy Der Text der Gnesener Predigten, kritisch beleuchtet. Z pracą biblioteczną zapoznał się w trakcie studiów, gdy pracował w Miejskiej Bibliotece we Wrocławiu. Podczas jego kierownictwa nastąpił rozwój księgozbioru Biblioteki TPN w Poznaniu. Większość nowych nabytków pochodziła z darów, m.in. z bibliotek prywatnych Kazimierza Szulca, ks. Franciszka Malinowskiego, Stefana Żychlińskiego, Jana Pawła Łuszczewskiego oraz biblioteki Towarzystwa Literacko-Słowiańskiego we Wrocławiu. Środki na powiększenie księgozbioru pozyskiwał też przez sprzedaż dubletów. W związku z tym ogłosił Spis duplikatów Tow. Przyjaciót Nauk (Poznań 1891) oraz Katalog duplikatów Biblioteki Tow. Przyjaciót Nauk w Poznaniu (Poznań 1897). Założył i opracował przeznaczony dla czytelników katalog książkowy, kontynuowany przez jego następców do 1953 roku. Ponadto opracował katalogi: dysertacji, inkunabułów, map, atlasów i muzykaliów. W 1895 roku wyodrębnił z całości zbiorów rękopisy. Z jego inicjatywy powstał Regulamin Biblioteki TPN (Poznań 1916), który obowiązywał do 1954 roku. Uporządkował archiwum (rodowe) Sułkowskich, przywiezione w 1911 roku z Rydzyny. W całej Wielkopolsce zbierał fundusze na rozbudowę gmachu bibliotecznego, która trwała od 1908 do 1911 roku. Po zakończeniu pracy w towarzystwie, w latach 1919-1920 był dyrektorem Archiwum Państwowego w Poznaniu.

W latach studiów Bolesław Erzepki współpracował z Karolem Estreicherem przy powstawaniu Bibliografii polskiej, przesyłając mu informacje o drukach śląskich z bibliotek wrocławskich. Potem informował Stanisława Estreichera o drukach wielkopolskich (zwłaszcza leszczyńskich) i nieznanych drukach z końca XVIII wieku. Od 1875 roku ogłosił kilkadziesiąt publikacji z archeologii, bibliografii, numizmatyki, językoznawstwa i historii literatury. Jako konserwator zbiorów wydał polsko- i niemieckojęzyczne katalogi galerii malarstwa oraz albumy z reprodukcjami najcenniejszych zabytków archeologicznych TPN w Poznaniu. W latach 1887-1889 współredagował „Zapiski Archeologiczne” (organ Komisji Archeologicznej TPN w Poznaniu). Wydał odnalezione przez siebie w rękopisach glosy polskie 
oraz próbki gwary mazowieckiej. Ogłosił drukiem Słownik łacińsko-polski Bartłomieja z Bydgoszczy, za co otrzymał w 1895 roku nagrodę Akademii Umiejętności w Krakowie. Wyszukiwał w bibliotekach i wydawał nieznane wcześniej materiały źródłowe oraz polskie utwory literackie, m.in. Wacława Potockiego, Juliusza Słowackiego, Wojciecha Stanisława Chrościńskiego, Franciszka Zabłockiego, Cypriana Kamila Norwida. Zebrał i wydał materiały Wojciecha Adamskiego dotyczące flory Wielkiego Księstwa Poznańskiego.

Był prezesem Wydziału Historyczno-Literackiego (w latach 1893-1914) i członkiem honorowym TPN w Poznaniu, członkiem Zarządu Towarzystwa Przyjaciół Biblioteki Uniwersyteckiej w Poznaniu, członkiem honorowym Instytutu Zachodniosłowiańskiego, współorganizatorem i wiceprezesem Towarzystwa Ludoznawczego w Poznaniu, profesorem honorowym Uniwersytetu Poznańskiego (UP), członkiem Komisji Antropologicznej, Komisji Językowej i Komisji Literackiej oraz członkiem korespondentem Wydziału Filologicznego Akademii Umiejętności w Krakowie. Otrzymał Krzyż Komandorski Polonia Restituta (1921) i nagrodę literacką im. Józefa Łukaszewicza (1928). Zmarł 27 marca 1932 roku w Poznaniu?.

Bolesław Erzepki zgromadził obszerne notatki bio- i bibliograficzne, wycinki z gazet dotyczące historii i kultury Wielkopolski oraz sławnych Wielkopolan (głównie z XIX wieku), a także liczącą ponad 2000 listów korespondencję. Wszystkie te zbiory, zdeponowane na początku II wojny światowej przez żonę Różę Erzepki w Archiwum Archidiecezjalnym w Poznaniu, zostały przez Niemców wywiezione w nieznanym kierunku i zaginęły. Zachowały się natomiast tzw. Teki wielkopolskie, znajdujące się obecnie w Bibliotece Raczyńskich w Poznaniu wraz z inwentarzem opracowanym przez Andrzeja Wojtkowskiego. Są to notatki i wyciagi z rękopisów lub starych druków, do zamierzonych prac językoznawczych i historycznoliterackich. Obecnie znajdują się w Dziale Zbiorów Specjalnych Biblioteki Raczyńskich i obejmują rękopisy o numerach 1271-1367.

7 T. Ziółkowski, Erzepki Bolesław, w: Polski słownik biograficzny, t. 6, s. 294-295; I. Litwiak, Erzepki Bolesław, w: Słownik pracowników ksiażki polskiej, s. 205-206; J. Pietrowicz, Bolesław Erzepki 1852-1932, w: Słownik bibliotekarzy wielkopolskich 1918-2000, Poznań 2001, s. 52-55.

${ }^{8}$ W Tekach Bolesława Erzepkiego znajdują się m.in.: roty przysiąg z ksiąg grodzkich gnieźnieńskich, poznańskich, pyzdrskich (rkp. 1271) i kościańskich (rkp. 1272); glosy polskie w średniowiecznych rękopisach łańcuckich (rkp. 1273) i średniowiecznych kazaniach łacińskich (rkp. 1274); teksty polskie z pierwszej połowy XVI wieku (rkp. 1276); teksty polskie z XV wieku (rkp. 1277); alfabetyczny słownik polsko-łaciński z XV wieku (rkp. 1279-1280 i 1282-1284); kartkowy słownik średniowiecznych wyrazów polskich (rkp. 1286); kartkowy słownik nazwisk i imion wielkopolskich 
Oprócz nich również w zbiorze rękopisów Biblioteki PTPN zachowały się materiały po Bolesławie Erzepkim?. Warto też nadmienić, że w bi-

(rkp. 1287); kartkowy słownik wyrazów wielkopolskich (rkp. 1288); materiały dot. kalendarzy polskich z XV i XVI wieku (rkp. 1290); materiały dot. Mikołaja Reja (rkp. 1293); odpis dialogu Erazma z Rotterdamu pt. Coniugium Eulalia, Xantippe z glosami polskimi (rkp. 1294); zbiór utworów o nazwie Ze skarbca literatury polskiej XVI i XVII w. (rkp. 1295); materiały dot. Jana Kochanowskiego (rkp. 1296-1299); materiały dot. Marcina Kromera (rkp. 1300-1301); materiały dot. Sebastiana Fabiana Klonowicza (rkp. 1302); Kazanie a nauki na niedziele pirwsza Adwentowa (rkp. 1307); wiersze polskie i łacińskie wypisane z Silva rerum z Kobylegopola (rkp. 1308); materiały dot. Widawskich i wypisy z Silva rerum Widawskich (rkp. 1310); słownik kartkowy do Kaspara Miaskowskiego (rkp. 1311); Splendor Poloniae Gentis. Autore Venceslav Potocki Pocislatore Cracoviensi (rkp. 1312); poezje Wespazjana Kochowskiego (rkp. 1313); materiały dot. Opalińskich (rkp. 1314); poezje religijne (rkp. 1315); wiersze polskie z XVII wieku z rękopisu N 13 o nieustalonym miejscu przechowywania (rkp. 1316-1317); Dyariusz więzienia moskiewskiego miast i miejsc spisany przez Adama Kamieńskiego (rkp. 1319); materiały dot. Stanisława Przyjemskiego (rkp. 1320); kopie 16 listów bpa Hieronima Wierzbowskiego (rkp. 1321); materiały dot. Adama Naruszewicza (rkp. 1322); materiały dot. Ignacego Krasickiego (rkp. 1323); poezje i przekłady Onufrego Korytyńskiego w odpisach (rkp. 1324); materiały dot. Stanisława Trembeckiego (rkp. 1325); materiały dot. Józefa Bielawskiego (rkp. 1326); materiały dot. Franciszka Karpińskiego (rkp. 1327); materiały dot. Antoniego Felicjana Nagłowskiego (rkp. 1329); materiały dot. Kajetana Węgierskiego (rkp. 1330); materiały dot. Franciszka Zabłockiego (rkp. 1331); kopie wierszy (rkp. 1334-1337); dziennik księcia gen. Antoniego Sułkowskiego z lat 1823, 1826 i 1830 (rkp. 1338); materiały dot. Adama Mickiewicza (rkp. 1339); spis artykułów drukowanych w „Orędowniku Naukowym” (rkp. 1340); materiały dot. Zygmunta Krasińskiego (rkp. 1341); kopie listów Klementyny z Tańskich Hoffmanowej (rkp. 1342); materiały dot. Tomasza Augusta Olizarowskiego (rkp. 1343); kopie utworów zamieszczanych w czasopiśmie „Goniec Polski” (rkp. 1345); materiały dot. Teofila Lenartowicza (rkp. 1347); kopie listów Jana Koźmiana oraz notatki i wycinki z gazet dot. Jana Koźmiana (rkp. 1348); kopie listów numizmatyków, głównie niemieckich (rkp. 1349); materiały dot. Juliana Klaczki (rkp. 1350, m.in. kopie listów i wycinki z gazet); materiały dot. Konstantego Zakrzewskiego (rkp. 1351-1352); wycinki z gazet i czasopism oraz notatki dot. wybitnych księży Wielkopolan (rkp. 1355); Formularz Królowej Jadwigi (rkp. 1358); wspomnienia Ludwika z Boncze Sienickiego Ciwona Retawskiego (rkp. 1363); tekst pt. Theatrum albo konterfekt żywota ludzkiego Stanisława Kołakowskiego (rkp. 1366) - na podstawie inwentarza rękopisów opracowanego przez Andrzeja Wojtkowskiego w Dziale Zbiorów Specjalnych Biblioteki Raczyńskich w Poznaniu.

${ }^{9}$ W Bibliotece PTPN znajdują się: Zbiór rękopisów Biblioteki Towarzystwa Przyjaciót Nauk w Poznaniu. Wykaz darów i nabytków od 1 lipca 1885 roku do końca 1895 roku (rkp. 804); wykaz nabytków rękopisów i dyplomów Biblioteki PTPN za lata 1891-1911 (rkp. 805); odpisy listów Cypriana Kamila Norwida do Cezarego Platera z lat 1846-1866 z oryginałów przechowywanych w dawnym Archiwum Czapskich w Smogulcu (rkp. 821); korespondencja Bolesława Erzepkiego z Jerzym Hulewiczem i Zenonem Przesmyckim (rkp. 822); odpisy listów Cypriana Kamila Norwida do Eleonory 
bliotece tej znajdują się materiały żony Róży i córki Heleny Erzepkich (rkp. 1224-1239), m.in. ich prace naukowe i literackie, dzienniki oraz korespondencja.

\section{Ludwika Dobrzyńska-Rybicka}

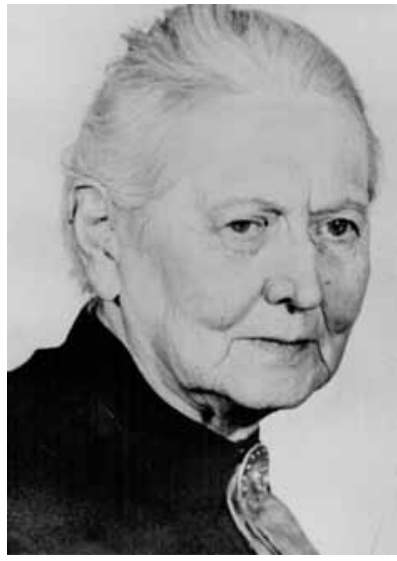

Od 6 maja 1909 roku w Bibliotece TPN w Poznaniu Bolesławowi Erzepkiemu pomagała Ludwika Dobrzyńska-Rybicka, która objęła kierownictwo biblioteki po jego przejściu na emeryturę w 1919 roku i sprawowała je do 1937 roku. 1 października 1919 roku biblioteka, pozostając własnością TPN w Poznaniu, przeszła na mocy umowy pod administrację Biblioteki Uniwersyteckiej w Poznaniu jako jej oddział. Ludwika Dobrzyńska-Rybicka urodziła się 19 listopada 1868 roku w Brzeżawie (powiat sanocki). Ukończyła wyższe seminarium nauczycielskie w szkole Ludwiki w Poznaniu, zdając w 1887 roku egzamin nauczycielski. Pracowała jako nauczycielka w Poznaniu, Iwnie i Kaliszu. W Kaliszu zajmowała się też dziennikarstwem i twórczością literacką. W "Gazecie Kaliskiej” ukazywały się jej recenzje, krytyki teatralne i nowele, a w „Przeglądzie Polskim" publikowano jej dramat zatytułowany Zygmunt Taszycki. W 1903

z Mielżyńskich Czapskiej z 1870 roku (rkp. 823); zbiór wycinków prasowych z lat 1849-1931 oraz notatek i wypisów dot. życia i twórczości Cypriana Kamila Norwida (rkp. 824); Sekretariat Zarzadu Towarzystwa Przyjaciół Nauk. Księga darów zaprowadzona od 1-go listopada 1881 r. (rkp. 930); dokumentacja dot. przekazania przez Ludwika Korotyńskiego jego księgozbioru do Biblioteki PTPN w 1919 roku (rkp. 1219); notatki Bolesława Erzepkiego dot. pochodzenia jego rodziny (rkp. 1220); jego papiery osobiste z lat 1850-1956 (rkp. 1221); Wspomnienie o Bolesławie Erzepkim, wygłoszone na zebraniu Stowarzyszenia Bibliotekarzy Polskich - Oddział w Poznaniu w dniu 22.1.1953 r. autorstwa Anieli Koehlerówny (rkp. 1222); Rydzyna - nieznany wiersz Stanistawa Ropelewskigo. Z materiałów zebranych przez dr. Bolesława Erzepkiego opracowała R[óża] E[rzepki] z około 1937 roku (rkp. 1223); księga protokołów Wydziału Historyczno-Literackiego PTPN z okresu 23.10.1916-23.02.1920 (rkp. 1270); skorowidz rozpoczęty w 1915 roku przez Bolesława Erzepkiego, kontynuowany przez Ludwikę Dobrzyńską-Rybicką i Anielę Koehlerównę pt. Biblioteka Towarzystwa Przyj. Nauk w Poznaniu. Defekty. Nadchodzace czasopisma naukowe od sierpnia 1924 r. (rkp. 1402); sprawozdanie za rok 1890 pt. Zbiory Towarzystwa Przyjaciót Nauk w Poznaniu (rkp. 1427); spis darów przekazanych do zbiorów PTPN w latach 1893-1905 (rkp. 1467); listy TPN w Poznaniu do Bolesława Erzepkiego z lat 1882-1886 (rkp. 1530) - na podstawie Inwentarza rękopisów Biblioteki... 
roku rozpoczęła studia na Wydziale Filozoficznym Uniwersytetu w Zurychu. Studiowała tam filozofię ścisłą ze szczególnym uwzględnieniem etyki oraz uczestniczyła w wykładach z historii sztuki. W latach 1905-1906, mając prywatny tok studiów w Wyższym Instytucie Katolickiej Filozofii w Louvain (Lowanium), poznawała współczesną filozofię katolicką. Słuchała też wykładów w Collège de France w Paryżu i na Uniwersytecie w Oxfordzie, gdzie udała się po materiały do pracy doktorskiej. 16 stycznia 1909 roku uzyskała stopień doktora filozofii na podstawie rozprawy doktorskiej Die Ethik von Thomas Brown.

W trakcie pracy w Bibliotece PTPN sporządziła książkowy katalog alfabetyczny i kartkowy katalog systematyczny, który zaginął w czasie II wojny światowej. Wyodrębniła z magazynu głównego inkunabuły i częściowo je opracowała. Wydzieliła też XVI-wieczne druki polskie oraz Polski dotyczące i wraz z Anielą Koehlerówną opracowała Katalog druków polskich $X V I$ wieku, zawierający ponad 400 pozycji (jeden z pierwszych tego typu w Polsce). Publikowała artykuły, w których informowała o drukach z księgozbioru Biblioteki TPN w Poznaniu. Napisała pierwszą monografię tejże biblioteki, opublikowaną w 50. tomie „Roczników PTPN”. Opracowała też przewodnik po zbiorach towarzystwa, wydany w 1917 roku.

Od 1919 roku wykładała na UP filozofię, a od 1927 roku socjologię i naukę obywatelstwa. W 1920 roku habilitowała się na Uniwersytecie Jagiellońskim (UJ) na podstawie pracy System etyczny Hugona Kołłataja na podstawie źródeł rękopiśmiennych. W 1932 roku otrzymała tytuł profesora obywatelstwa, a w następnym roku została mianowana profesorem tytularnym UP. W czasie II wojny światowej mieszkała w Poznaniu i Śremie, prowadząc prywatne lekcje. Po zakończeniu działań wojennych wróciła na UP. W 1949 roku przeszła na emeryturę, nie przestając jednak pracować naukowo.

Ludwika Dobrzyńska-Rybicka brała czynny udział w życiu związkowym bibliotekarzy. Należała do Poznańsko-Pomorskiego Koła Związku Bibliotekarzy Polskich (ZBP). Była też członkiem zarządu ZBP. Była najpierw członkiem, a od 1928 roku zastępcą prezesa Towarzystwa Bibliofilów Polskich (założonego w 1923 roku). Od 1935 roku była członkiem korespondentem polskiej komisji ds. współpracy z Gesamtkatalog der Wiegendrucke. Wspólnie z pracownicą Biblioteki Uniwersyteckiej w Poznaniu Bożenną Szulc-Golską opracowała Katalog wystawy regionalnej ku czci J. Kochanowskiego zorganizowanej w Poznaniu w 1930 roku przez Poznańsko-Pomorskie Koło ZBP. Na II Międzynarodowy Kongres Bibliotekarzy (Madryt 1935) przesłała referat zatytułowany Ksiażka hiszpańska w bibliotekach poznańskich. 
Brała udział w wielu zjazdach i kongresach naukowych, m.in. w VI Międzynarodowym Kongresie Wychowania Moralnego (Kraków 1934), Zjeździe Socjologów (Warszawa 1935), III Polskim Zjeździe Filozoficznym (Kraków 1936), XI Międzynarodowym Kongresie Psychologicznym (Paryż 1937), IX Międzynarodowym Kongresie Filozoficznym (Paryż 1937), IV Międzynarodowym Kongresie w sprawie Jedności Wiedzy Naukowej (Cambridge 1938). Była członkiem Komisji Filozoficznej, Komisji Psychologicznej, Komisji Nauk Społecznych oraz Wydziału Historyczno-Literackiego PTPN, Wydziału Filozoficznego Polskiej Akademii Umiejętności oraz Towarzystwa Filozoficznego w Krakowie.

Była działaczką ruchu kobiecego. Walczyła o równouprawnienie kobiet w życiu politycznym i zawodowym. Współtworzyła Naczelną Organizację Kobiet (NOK). Działała w wielu organizacjach społecznych: Katolickim Związku Polek, Polskim Stowarzyszeniu Kobiet z Wyższym Wykształceniem „Przystań” w Poznaniu, Stowarzyszeniu „Służba Obywatelska” i Towarzystwie „Warta”. W 1918 roku była posłanką na Sejm Dzielnicowy.

Otrzymała między innymi: nagrodę im. abpa Edwarda Likowskiego za pracę o systemie etycznym Hugona Kołłątaja (1917), wyróżnienie honorowe za działalność plebiscytową na Śląsku (1921), Srebrny Wawrzyn Akademicki (1936) i Krzyż Oficerski Orderu Odrodzenia Polski (1937). Zmarła 7 października 1958 roku w Poznaniu ${ }^{10}$.

Znacząca część spuścizny Ludwiki Dobrzyńskiej-Rybickiej znajduje się w zbiorach Polskiej Akademii Nauk (PAN) Archiwum w Warszawie Oddział w Poznaniu (sygn. P.III-1). Materiały te zostały zakupione przez ówczesne Archiwum PAN Oddział w Poznaniu w 1958 roku, czyli jeszcze za jej życia. W chwili zakupu znajdowały się one w rozsypce, z wyjątkiem pracy o Romano Guardinim, która była ułożona w teczkach. Po opracowaniu (przez Zofię Wardęską) spuścizna obejmuje około półtora metra bieżącego akt i liczy 395 jednostek archiwalnych. W momencie przekazania do spuścizny dołączony był tymczasowy spis materiałów. Materiały Ludwiki Dobrzyńskiej-Rybickiej zostały podzielone na sześć działów: I - prace, II - materiały działalności, III - materiały biograficzne, IV - korespondencja, V - materiały o twórcy zespołu, VI - materiały osób trzecich.

Dział I obejmuje: prace i artykuły; wykłady; recenzje i opinie; referaty i przemówienia; utwory literackie oraz materiały warsztatowe. Wśród prac znalazły się teksty naukowe z zakresu filozofii, psychologii

${ }^{10}$ M. Plewkiewicz, Dobrzyńska-Rybicka Ludwika, w: Słownik pracowników książki polskiej, s. 176-177; A. Nowacka, Ludwika Dobrzyńska-Rybicka 1868-1958, w: Słownik bibliotekarzy wielkopolskich 1918-2000, s. 44-49. 
i socjologii ${ }^{11}$. Zachowało się też wiele artykułów ${ }^{12}$. Obszerna grupa wykładów obejmuje teksty wykładów z filozofii, psychologii, socjologii, etyki, estetyki i teodycei oraz notatki i wypisy do tychże wykładów. Szczególnie ciekawe są wykłady z socjologii, zwłaszcza z nauki obywatelstwa, które stanowiły teoretyczną podbudowę działalności NOK. Zachowały się recenzje kilku prac naukowych, recenzja sztuki teatralnej Dzwon zatopiony oraz opinia o Helenie Chwałkowskiej. Liczne są teksty referatów i przemówien ${ }^{13}$. Do utworów literackich zaliczono rękopisy: Ballada $z$ dawnych lat, Kilka uwag o Przybyszewskim, Z Genui przez Gibraltar do Algieru (1917), Zygmunt Taszycki (1900, redakcje 1-2) oraz inne drobne utwory. Obszerna jest grupa materiałów warsztatowych ${ }^{14}$.

Dział II obejmuje materiały działalności naukowej w: L'Assotiation Polono-Française de Poznań (1946), Polskiej Akademii Umiejętności (1938-1952), Polskim Towarzystwie Filologicznym - Koło Poznańskie (1951), Polskim Towarzystwie Filozoficznym w Warszawie - Sekcja Socjologiczna (1956-1957), Polskim Towarzystwie Psychologicznym - Oddział Poznański (1951-1954), Polskim Towarzystwie Socjologicznym (1959), Poznańskim Towarzystwie Filozoficznym (1950-1951), PTPN (1922-1957), Towarzystwie Filozoficznym w Krakowie (1949-1952) oraz Związku Bibliotekarzy i Archiwistów Polskich - Koło Poznańskie (1945-1953). Ponadto do materiałów działalności naukowej należą materiały z kongresów, zebrań, konferencji i zjazdów, w których brała udział Ludwika Dobrzyńska-Rybicka. Zachowały się też materiały działalności dydaktycznej na UJ

11 Między innymi: Filozoficzno-religijne i teologiczne poglady w pracach R. Guardiniego (niepublikowane, kilka redakcji z lat 1952-1956); Współczesny egzystencjalizm francuski (kilka redakcji z lat 1951-1952); Automatyzm graficzny (b.d.); Rola czynników społecznych w rozwoju świadomości moralnej (b.d.); Moc narodu a władza nad soba (b.d.); Z socjologii "kresów" (b.d.).

${ }^{12}$ Między innymi: Czasy kościuszkowskie na łamach wspótczesnej prasy wielkopolskiej; Dlaczego Polanie nie stworzyli epopei; Homo sapiens - przyczynek do dziejów ducha polskiego; Pochód najmłodszych; U kolebki ducha polskiego.

${ }^{13}$ Między innymi: Dzień zjednoczenia PPR i PPS (1948); Etyka starożytna. Etyka nowożytna (b.d.); Powodzenie życiowe (1947); Rola kobiety w katolickiej walce światopogladu (1930); Rzut oka na rozważania Jakuba Maritaina o życiu inteligencji właściwym i stopniach wiedzy (1950-1951); Zagadnienie istotności (około 1939); Z dziedziny psychologii współczesnej (b.d.).

${ }^{14}$ Obejmuje ona: a) notatki i wypisy (m.in. do prac: Automatyzm graficzny; Filozoficzno-religijne i teologiczne poglady w pracach $R$. Guardiniego; Une évolution médiuminique); b) ankiety (filozoficzna, religijna, pomysły, przeczucie, powołanie, sny, różnice między racjonalizmem a sensualizmem, umysły o cechach miękkich i twardych, wolna wola, zestawienie wyników ankiety psychologicznej); c) wycinki prasowe o problematyce bibliotecznej, filozoficznej, politycznej, religijnej i kobiecej oraz nekrologi. 
(1919-1920) i UP (1920-1957). Cenne są materiały działalności społecznej w: Katolickim Stowarzyszeniu Nauczycielek w Poznaniu (1912), Katolickim Związku Polek (1925), Klubie Demokratycznej Profesury (1950), Komitecie do spraw Szlachty Zagrodowej na Wschodzie Polski (1938-1939), NOK (1922-1939), Towarzystwie Obrony Społecznej w Poznaniu (1924), Towarzystwie Służby Obywatelskiej w Krakowie (1931) oraz Zakładzie im. hr. Tadeusza Garczyńskiego w Poznaniu (1945-1956). Do materiałów działalności społecznej zaliczono również materiały dotyczące wiecu kobiet w Bazarze Poznańskim (1918), zjazdu kobiet polskich w Częstochowie (1921), zjazdu kobiet w Rzymie (1925) oraz konferencji religijnych z lat 1906-1913.

Do materiałów biograficznych należą: świadectwa szkolne, dyplomy uniwersyteckie i nominacje (1883-1920), dyplom doktorski i jego kopie (1909), świadectwo urodzenia i zaświadczenia (1904-1953), dokumentacja emerytalna i umowy o pracę (1936-1958), odznaczenia (1936-1937), życiorysy, życiorys ankieta Słownika biograficznego ksią̇ki polskiej (1955-1956), spisy prac, pamiętnik (1895-1905), kalendarze z notatkami (1939-1948), notatki rekolekcyjne (1893-1950), notatki z konwersatoriów w Cambridge (1938), notatki ze studiów zagranicznych (1905-1908), rachunki (1910-1956), korespondencja w sprawie wyjazdu do Zurychu, fotografie, gratulacje (1909-1957), zaproszenia (1919-1957) oraz wspomnienia zatytułowane Bolesław Erzepki - garść osobistych wspomnień (1934) i Lucy Hoesch-Ernst, Erinnerungen einer Freundin (1949-1953).

Korespondencja, wychodząca i wpływająca, jest znaczącą częścią spuścizny. Odzwierciedla liczne kontakty Ludwiki Dobrzyńskiej-Rybickiej, zarówno naukowe, jak i towarzyskie. Korespondencję dotyczącą wyjazdu do Zurychu zaliczono do materiałów biograficznych, a korespondencję z towarzystwami naukowymi do materiałów działalności.

Materiały o twórcy spuścizny obejmują: uwagi o wykładach Ludwiki Dobrzyńskiej-Rybickiej zamieszczane w prasie (1910-1929), recenzje jej utworów literackich (1901), recenzję pracy Ludwiki Dobrzyńskiej-Rybickiej i Heleny Witkowskiej Obywatelstwo jako podstawa życia zbiorowego w odrodzonej Polsce (1931) oraz ocenę rękopisu System etyczny H. Kołtataja (1915). Wśród materiałów osób obcych znalazły się artykuły, recenzje, wspomnienia i listy ${ }^{15}$.

Część spuścizny Ludwiki Dobrzyńskiej-Rybickiej trafiła do zbioru rękopisów Biblioteki PTPN. Większość znajduje się w obrębie spuścizny Anieli Koehlerówny, która gromadziła jej materiały archiwalne, i obejmuje

${ }^{15}$ Z. Wardęska, Materiały Ludwiki Dobrzyńskiej-Rybickiej, PAN Archiwum w Warszawie Oddział w Poznaniu. 
sygnatury 1291-1312 ${ }^{16}$. Dalsza część jej materiałów w zbiorze rękopisów Biblioteki PTPN ma sygnatury rkp. 1476-1480. Są tam: materiały dotyczące jej działalności na UP w latach 1933-1936 (rkp. 1476); pierwsza wersja tekstu Biblioteka zamieszczonego w książce Towarzystwo Przyjaciót Nauk w Poznaniu w latach 1857-1927 (Poznań 1928, rkp. 1477); brudnopis referatu Le livre espagnol dans les bibliothéques de Poznań (rkp. 1478); tekst O zawodzie bibliotekarskim (rkp. 1479); materiały dotyczące jej działalności w organizacjach kobiecych (rkp. 1480) ${ }^{17}$.

W Archiwum Uniwersytetu im. Adama Mickiewicza w Poznaniu zachowały się dwie teczki Ludwiki Dobrzyńskiej-Rybickiej. Znajdują się w nich materiały dotyczące jej zatrudnienia na UP w okresie międzywojennym (sygn. 152/7) oraz w latach 1945-1948 (sygn. 638/468). W Archiwum Biblioteki Uniwersyteckiej w Poznaniu przechowywane są materiały dotyczące przebiegu jej pracy w tejże bibliotece (sygn. 28).

\section{Jan Baumgart}

Następcą Ludwiki Dobrzyńskiej-Rybickiej na stanowisku dyrektora Biblioteki PTPN był Jan Baumgart. Pełnił tę funkcję od 1 września 1937 roku do 31 grudnia 1947 roku. Urodził się 3 marca 1904 roku w Wudzynku na

16 Znajdują się tam: biogramy, notatki biograficzne i wspomnienia pośmiertne Ludwiki Dobrzyńskiej-Rybickiej (rkp. 1291); jej papiery osobiste z lat 1925-1958 (rkp. 1292); korespondencja z lat 1905-1958 (rkp. 1293); dzienniki z lat 1904-1905 i 1914-1956 (rkp. 1294-1296); wspomnienia o matce - Ludwice z Moraczewskich Dobrzyńskiej pt. Matula (rkp. 1297); notatniki z lat 1888-1918 z zapisami wydatków domowych (rkp. 1298); przepisy kulinarne i porady dot. prowadzenia gospodarstwa domowego Franciszki z Zakrzewskich Moraczewskiej dla córki Ludwiki z Moraczewskich Dobrzyńskiej z drugiej połowy XIX wieku (rkp. 1299); książeczka adresowa Ludwiki Dobrzyńskiej-Rybickiej z lat 1945-1948 (rkp. 1300); materiały dot. jej działalności administracyjnej w Zakładzie Garczyńskich w Poznaniu w 1945 roku (rkp. 1301); bibliografia prac i recenzji (rkp. 1302); tekst prelekcji dla kobiet pt. Kościuszko. Sylwetka psychologiczno-etyczna z przełomu XIX i XX wieku (rkp. 1303); tekst utworu dramatycznego pt. Ostatnie chwile Joanny d'Arc z około 1900 roku z adnotacjami cenzury rosyjskiej (rkp. 1304); tekst opowiadania pt. Mare tenebrarum z początku XX wieku (rkp. 1305); tekst pt. „Nowy człowiek” w świetle myśli współczesnej (rkp. 1306); zbiór drobnych prac (m.in. O zawodzie bibliotekarskim) oraz konspekty wykładów religijnych (rkp. 1307); wspomnienia z lat 1904-1914 dot. przyjaciółki ze studiów w Zurychu pt. Lucy Hoesch-Ernst. Erinnerungen einer Freundin (rkp. 1310); listy z jej artykułami przesyłanymi ze Szwajcarii do gazet poznańskich, warszawskich i lwowskich (rkp. 1311); wspomnienia przyjaciółki Anny Wolskiej (rkp. 1312) - na podstawie Inwentarza rękopisów Biblioteki...

${ }^{17}$ Inwentarz rękopisów Biblioteki..., s. 452-453. 
Pomorzu. Studiował historię na UP. W 1928 roku uzyskał dyplom magistra filozofii w zakresie historii i języka niemieckiego. W tym samym roku został urzędnikiem kontraktowym w Archiwum Państwowym w Bydgoszczy. W latach 1928-1931 pracował jako nauczyciel w gimnazjum w Koźminie i Seminarium Nauczycielskim w Tucholi.

W grudniu 1931 roku rozpoczął pracę w Bibliotece Uniwersyteckiej w Poznaniu (jako asystent biblioteczny). Przeszedł wszystkie szczeble bibliotekarskiej kariery zawodowej. W 1935 roku zdał egzamin dla kandydatów do państwowej

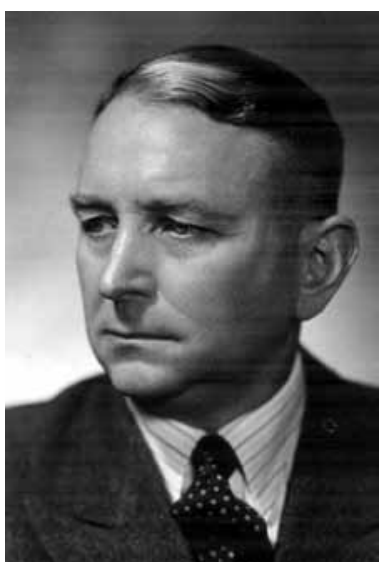
służby bibliotecznej. Większość okupacji hitlerowskiej spędził w Krakowie, gdzie od sierpnia 1941 roku pracował w ówczesnej Staatsbibliothek (Bibliotece Jagiellońskiej) - w czytelni głównej i w referacie informacji bibliograficznej. Działał też w podziemnym Departamencie Oświaty i Kultury.

W marcu 1945 roku powrócił do pracy w Bibliotece Uniwersyteckiej w Poznaniu, z której upoważnienia do końca 1947 roku był dyrektorem Biblioteki PTPN. W tym czasie zdołał odbudować od podstaw księgozbiór oraz wyposażyć Bibliotekę PTPN w niezbędne sprzęty. W 1945 roku uzyskał na UP stopień doktora z historii i bibliologii na podstawie rozprawy Bracia Sułkowscy. W styczniu 1948 roku rozpoczął ponownie pracę w Bibliotece Jagiellońskiej w Krakowie, gdzie objął stanowisko zastępcy dyrektora i kierownika Działu Udostępniania Zbiorów. Od 1955 roku do przejścia na emeryturę w 1974 roku pełnił funkcję dyrektora Biblioteki Jagiellońskiej. Przeprowadził w niej reformę katalogów, zreorganizował czytelnictwo i opracowanie zbiorów, organizował wystawy, przyczynił się do wzrostu liczby publikacji naukowych i rozwinięcia wymiany wydawnictw z ośrodkami zagranicznymi. Opracował projekt rozbudowy gmachu Biblioteki Jagiellońskiej, zrealizowany w latach 1961-1963.

W latach 1951-1953 wykładał na Wydziale Filologicznym i Historycznym UJ. Ponadto był twórcą i kierownikiem Międzywydziałowego Studium Bibliotekoznawstwa UJ (1969-1975). W 1972 roku został profesorem nadzwyczajnym UJ. W latach 1974-1977 prowadził wykłady w Zakładzie Bibliotekoznawstwa i Informacji Naukowej Instytutu Filologii Polskiej UJ oraz w Wyższej Szkole Pedagogicznej w Kielcach. W tej ostatniej kierował Studium Bibliotekoznawstwa i Informacji Naukowej. Jako członek komisji egzaminacyjnych prowadził egzaminy dla kandydatów do państwowej służby bibliotecznej (1946-1949), egzaminy praktyk międzybibliotecznych (1955-1959), egzaminy dla bibliotekarzy dyplomowanych 
(1962-1971 - jako zastępca przewodniczącego komisji, 1971-1974 - jako przewodniczący komisji). W 1956 roku został docentem w PAN. W latach 1953-1968 jako pracownik Instytutu Historii PAN był inicjatorem i redaktorem Bibliografii historii polskiej (za lata 1944-1967). W latach 1956-1972 był członkiem Komisji do spraw Bibliotek i Informacji Naukowej Rady Głównej Nauki, Szkolnictwa Wyższego i Techniki, a od 1960 roku zastępcą przewodniczącego. Następnie w latach 1973-1976 był członkiem Komisji Informacji Naukowej, Bibliotek, Wydawnictw i Bazy Poligraficznej Rady Głównej Nauki, Szkolnictwa Wyższego i Techniki. Był też członkiem Sekcji Bibliotek i Czytelnictwa Rady Kultury i Sztuki (1959-1966), Rady Kultury i Sztuki (1966-1970) oraz Prezydium Państwowej Rady Bibliotecznej i przewodniczącym Sekcji do spraw Zbiorów Bibliotecznych (1969-1970).

W latach 1954-1967 kierował Oddziałem Krakowskim Stowarzyszenia Bibliotekarzy Polskich (SBP). Od 1947 roku był członkiem Zarządu Głównego SBP, a w latach 1966-1969 przewodniczącym SBP. W latach 1955-1970 pracował w komitecie redakcyjnym „Przeglądu Bibliotecznego". W 1970 roku został członkiem podsekcji bibliotek uniwersyteckich IFLA. Dla Comité International des Sciences Historiques w Paryżu opracował zestawienie polskiego piśmiennictwa historycznego w latach 1947-1973. Był autorem około 230 publikacji naukowych, głównie z zakresu bibliotekoznawstwa. W 1983 roku ukazał się wybór prac Jana Baumgarta zatytułowany Bibliotekarstwo, biblioteki, bibliotekarze.

Otrzymał liczne odznaczenia i nagrody, m.in. Krzyż Kawalerski Orderu Odrodzenia Polski (1956), odznakę Zasłużony Działacz Kultury (1964), Odznakę Tysiąclecia Państwa Polskiego (1965), Honorową Odznakę SBP (1968), Medal Komisji Edukacji Narodowej (1976), tytuł członka honorowego SBP (1977) oraz Krzyż Komandorski Orderu Odrodzenia Polski (1985). Zmarł 17 sierpnia 1989 roku w Krakowie ${ }^{18}$.

W zbiorach rękopisów Biblioteki PTPN zachowały się teksty autorstwa Jana Baumgarta związane z pracą na stanowisku dyrektora: sprawozdania i statystyki roczne Biblioteki PTPN z lat 1937-1939 (rkp. 1463) oraz Losy Biblioteki Poznańskiego Towarzystwa Przyjaciół Nauk z grudnia 1946 roku i Biblioteka Poznańskiego Towarzystwa Przyjaciót Nauk. (Odbudowa Biblioteki w latach 1945-46) ze stycznia 1947 roku (oba teksty: rkp. $1282)^{19}$.

${ }^{18}$ H. Tadeusiewicz, Baumgart Jan, w: Słownik pracowników książi polskiej. Suplement 2, Warszawa 2000, s. 18-19; H. Wieland, Jan Baumgart 1904-1989, w: Stownik bibliotekarzy wielkopolskich 1918-2000, s. 16-19.

${ }^{19}$ Inwentarz rękopisów Biblioteki..., s. 338, 446. 
Materiały Jana Baumgarta dotyczące przebiegu jego pracy w Bibliotece Uniwersyteckiej w Poznaniu znajdują się w archiwum tejże biblioteki (sygn. 15). Wśród nich są między innymi wycinki prasowe dotyczące kursów bibliotekarskich i działalności Poznańsko-Pomorskiego Koła ZBP, korespondencja z ministrem wyznań religijnych i oświecenia publicznego, opinie dyrektora Biblioteki Uniwersyteckiej Stefana Vrtela-Wierczyńskiego, podania o zmianę uposażenia, sprawozdanie z pracy zatytułowane Przebieg pracy bibliotecznej w Bibliotece Uniwersyteckiej w Poznaniu (1934). Ponadto znajduje się tam jego korespondencja z dyrekcją Biblioteki Uniwersyteckiej w Poznaniu z 1948 roku na temat strat poniesionych przez tę bibliotekę w latach 1939-1945 (sygn. 551). Również w Archiwum Biblioteki Jagiellońskiej w Krakowie znajdują się akta i papiery osobiste Jana Baumgarta.

\section{Aniela Koehlerówna}

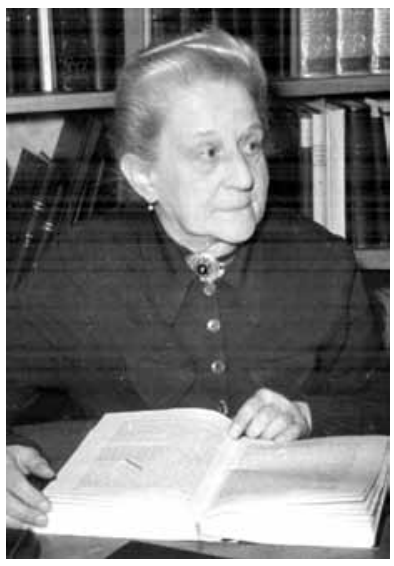

Następczynią Jana Baumgarta została Aniela Koehlerówna, która najpierw od 1 stycznia 1948 do 1 czerwca 1956 roku pełniła funkcję kierowniczki, a następnie od 2 czerwca 1956 do 31 stycznia 1963 roku była dyrektorem Biblioteki PTPN. Urodziła się 8 listopada 1882 roku w Kościanie. W Krakowie w latach 1901-1903 chodziła na kursy Baranieckiego dla kobiet oraz na wykłady z zakresu historii literatury polskiej na UJ. W latach 1903-1904 jako wolna słuchaczka uczęszczała na wykłady z literatury i sztuki na Sorbonie. W latach 1905-1914 prowadziła działalność społeczno-oświatową w kobiecych towarzystwach oświatowych w Poznaniu oraz działała w Komisji Recenzyjnej Towarzystwa Czytelni Ludowych.

15 grudnia 1916 roku rozpoczęła pracę w Bibliotece PTPN. Pod kierunkiem Bolesława Erzepkiego i Ludwiki Dobrzyńskiej-Rybickiej zdobyła doświadczenie w zawodzie bibliotekarskim, współtworząc przeznaczony dla czytelników katalog alfabetyczny oraz systematyczny. W latach 1919-1920 uczestniczyła w kursie bibliotekarskim prowadzonym przez dyrektora Biblioteki Uniwersyteckiej w Poznaniu Edwarda Kuntze. Od 1920 roku należała do ZBP. Była delegatem na zjazdy i członkiem Komisji Rewizyjnej Okręgu Poznańskiego ZBP. W latach 1927-1937 prowadziła bibliotekę oddziału poznańskiego Towarzystwa Polsko-Włoskiego „Dante Alighieri”. Pod koniec 1939 roku została wysiedlona z Poznania. 
Od sierpnia 1940 roku do 1 sierpnia 1944 roku pracowała jako kierowniczka wypożyczalni w Bibliotece Uniwersyteckiej w Warszawie. W marcu 1945 roku powróciła do Poznania. W latach 1945-1947 pełniła funkcję zastępcy dyrektora Biblioteki PTPN. Do jej zadań należała odbudowa zniszczonego księgozbioru. Odnalazła znaczną część książek i czasopism, księgi inwentarzy bibliotecznych oraz katalog kartkowy. Księgozbiór ten został udostępniony czytelnikom 1 stycznia 1948 roku w wyremontowanych pomieszczeniach biblioteki. Za czasów jej kierownictwa - w 1953 roku - Biblioteka PTPN wyszła spod administracji Biblioteki Uniwersyteckiej w Poznaniu i przeszła pod opiekę PAN. W latach jej dyrekcji wykonano nowy katalog kartkowy i systematyczny, odtworzono zaginiony inwentarz, przeprowadzono skontrum oraz zorganizowano wiele wystaw. Ministerstwo Oświaty przekazało jej fundusze na katalogowanie księgozbiorów podworskich, a PAN na remont, urządzenie większej czytelni i wyposażenie pracowni bibliotecznych. Aniela Koehlerówna była też członkiem Komisji Filologicznej PTPN.

Pierwsze artykuły, przeważnie o tematyce historycznej, kulturalnej i religijnej, publikowała głównie w prasie poznańskiej, m.in. w „Kurierze Poznańskim". Pisała również artykuły o sytuacji i działalności kobiet w Polsce i na świecie, o ruchu kobiecym i jego działaczkach. Gromadziła materiały dotyczące historii ruchów kobiecych. Razem z Ludwiką Dobrzyńską-Rybicką opublikowała: Druki wielkopolskie z roku 1916 („Roczniki Towarzystwa Przyjaciół Nauk Poznańskiego" 44, 1917), Zestawienie literatury polskiej odnoszacej się do historii W. Ks. Poznańskiego za rok 1916 (ibidem) i Katalog druków polskich XVI w. znajdujących się w Bibliotece TPN w Poznaniu (Poznań 1929). Opracowała wspomnienia pośmiertne o Ludwice Dobrzyńskiej-Rybickiej („Sprawozdania PTPN” 1958, nr 3; „Przegląd Biblioteczny" 1959). Pisała o zbiorach rękopiśmiennych Biblioteki PTPN w Informatorze o zbiorach rękopiśmiennych bibliotek polskich (Wrocław 1960) i o dziejach Biblioteki PTPN (m.in. Biblioteka Poznańskiego Towarzystwa Przyjaciót Nauk 1857-1957, „Roczniki Historyczne” 33, 1957).

Została odznaczona między innymi medalem i dyplomem Societa Nazionale Dante Alighieri w Rzymie (1937, za prowadzenie biblioteki Towarzystwa Polsko-Włoskiego w Poznaniu), Srebrnym Krzyżem Zasługi (1938), brązowym medalem za długoletnią służbę w bibliotekarstwie (1938), Krzyżem Kawalerskim Orderu Odrodzenia Polski (1957). Zmarła 17 listopada 1969 roku w Poznaniu ${ }^{20}$.

${ }^{20}$ B. Świderski, Koehlerówna Aniela, w: Słownik pracowników ksią̇ki polskiej, s. 426-427; J. Pietrowicz, Aniela Koehlerówna 1882-1969, w: Słownik bibliotekarzy wielkopolskich 1918-2000, s. 78-81. 
Spuścizna Anieli Koehlerówny znajduje się w zbiorze rękopisów Biblioteki PTPN. Została tam przekazana w 1970 roku. Zawiera materiały Anieli Koehlerówny, omówione wcześniej materiały Ludwiki Dobrzyńskiej-Rybickiej oraz wspomnienia Anny Wolskiej i pamiętnik Marii Studniarskiej (1871-1890). Na właściwą spuściznę Anieli Koehlerówny składają się: jej materiały biograficzne (m.in. zaświadczenia Biblioteki Uniwersyteckiej w Poznaniu upoważniające ją do urzędowego gromadzenia i zabezpieczania dzieł naukowych na terenie Poznania) i korespondencja z lat 1918-1963 (rkp. 1285); bibliografia prac własnych w formie kartoteki (rkp. 1286); dziennik z lat 1945-1946 dotyczący głównie prac nad rekonstrukcją księgozbioru i reorganizacją Biblioteki PTPN (rkp. 1287); bibliografia, wypisy i notatki do planowanej biografii ks. Jana Koźmiana (rkp. 1288); bibliografie dotyczące działalności kobiet w Polsce i ruchu kobiecego (rkp. 1289); historia Biblioteki TPN w Poznaniu z około 1912 roku (rkp. 1290)21. Materiały jej działalności zawodowej znajdują się w Archiwum Biblioteki Uniwersyteckiej w Poznaniu (sygn. 123).

\section{Bernard Olejniczak}

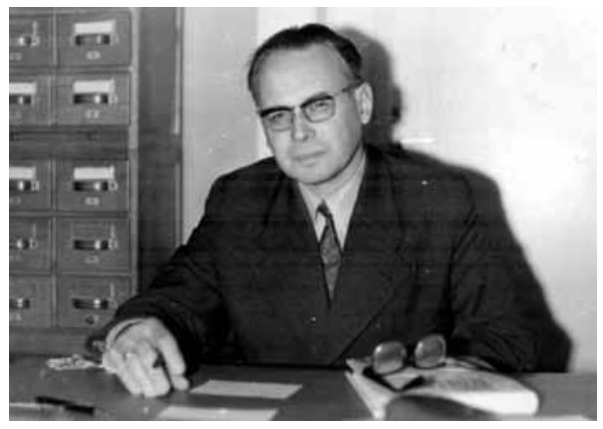

Po przejściu Anieli Koehlerówny na emeryturę dyrektorem Biblioteki PTPN został Bernard Olejniczak. Urodził się 29 listopada 1919 roku w Kościanie. W 1938 roku rozpoczął studia w Wyższej Szkole Handlowej w Poznaniu, których nie ukończył wskutek wybuchu wojny. Okres okupacji hitlerowskiej spędził na Podkarpaciu. W latach 1943-1945 walczył w Batalionach Chłopskich. Po wojnie rozpoczął studia z filologii romańskiej na UP, które ukończył w 1948 roku, uzyskując tytuł magistra filozofii. W styczniu 1949 roku podjął pracę w Publicznej Bibliotece Miejskiej im. Raczyńskich w Poznaniu, prowadząc najpierw jeden z punktów bibliotecznych. W czerwcu 1949 roku objął kierownictwo Działu Rezerw, a następnie - w październiku tegoż roku - Działu Zbiorów Specjalnych. W 1950 roku wziął udział w I Ogólnopolskim Kursie Rękopiśmienniczym w Krakowie, a po jego zakończeniu rozpoczął opracowywanie zbiorów rękopiśmiennych Publicznej Biblioteki Miejskiej im. Raczyńskich

\footnotetext{
${ }^{21}$ Inwentarz rękopisów Biblioteki..., s. 340-342.
} 
w Poznaniu. W 1957 roku został kierownikiem, a 1 stycznia 1958 roku dyrektorem tej biblioteki. Jako dyrektor położył największy nacisk na opracowanie jej zbiorów specjalnych. Prezydium Miejskiej Rady Narodowej zwolniło go ze stanowiska dyrektora z dniem 1 lipca 1962 roku. Jednym z powodów zwolnienia był spadek liczby czytelników. Do końca 1962 roku pracował w tej bibliotece na stanowisku kustosza.

W 1963 roku objął stanowisko dyrektora Biblioteki PTPN. Pełnił tę funkcję do 31 grudnia 1979 roku. Jako dyrektor urządził obszerne magazyny biblioteczne, usuwał słabo wykorzystywane książki i czasopisma, wprowadził katalog systematyczny, osobiście skatalogował i zaopatrzył w indeksy ponad 1000 rękopisów, redagował spis członków PTPN (opublikowany w „Rocznikach Historycznych” 1982). Władze PAN, która patronowała Bibliotece PTPN, wysłały go trzykrotnie za granicę, celem przeprowadzenia reorganizacji księgozbiorów w stacjach naukowych PAN w Rzymie i Paryżu. W latach 1953-1966 był wykładowcą i egzaminatorem Państwowego Ośrodka Kształcenia Korespondencyjnego Bibliotekarzy w Wojewódzkim Punkcie Konsultacyjnym w Poznaniu. Był redaktorem i współautorem podręcznika uniwersyteckiego Organizacja i administracja biblioteki (Warszawa 1964). Razem z dyrektorem Biblioteki Kórnickiej Stefanem Weymanem współtworzył Komisję Koordynacyjną Bibliotek Wielkopolskich. Działał w SBP, m.in. jako przewodniczący Zarządu Okręgu m. Poznania w latach 1960-1961 oraz członek Prezydium Zarządu Głównego w latach 1963-1966. Z upoważnienia SBP uczestniczył w przygotowaniu i organizacji Kongresu Kultury Polskiej w 1966 roku. Z końcem 1979 roku przeszedł na emeryturę, ustępując stanowisko dyrektora Biblioteki PTPN Ryszardowi Marciniakowi. Został odznaczony Odznaką Honorową Miasta Poznania, Odznaką Honorową Za Zasługi w Rozwoju Województwa Poznańskiego, Złotym Krzyżem Zasługi, Krzyżem Kawalerskim i Krzyżem Oficerskim Orderu Odrodzenia Polski (1982). Zmarł 28 października 2003 roku².

Spuścizna Bernarda Olejniczaka została przekazana Bibliotece PTPN w depozyt przez jego syna prof. dra hab. Adama Olejniczaka w latach 2008-2010. Zgodnie z wolą deponenta po 20 latach przejdzie ona na własność biblioteki. Może być wykorzystywana wyłącznie do celów naukowych $^{23}$.

${ }^{22}$ R. Marciniak, Bernard Olejniczak (29 XI 1919-28 X 2003). Wspomnienie pośmiertne, „Winieta” 2004, nr 1, s. 3, 5.

${ }^{23}$ Spuścizna Bernarda Olejniczaka zawiera: wspomnienia i dzienniki z pobytów w Niemczech (rkp. 2082), Włoszech (rkp. 2083) oraz Paryżu i Wiedniu (rkp. 2084); wspomnienia z lat 1939-1949 dot. kampanii wrześniowej, służby w Batalionach 


\section{Ryszard Marciniak}

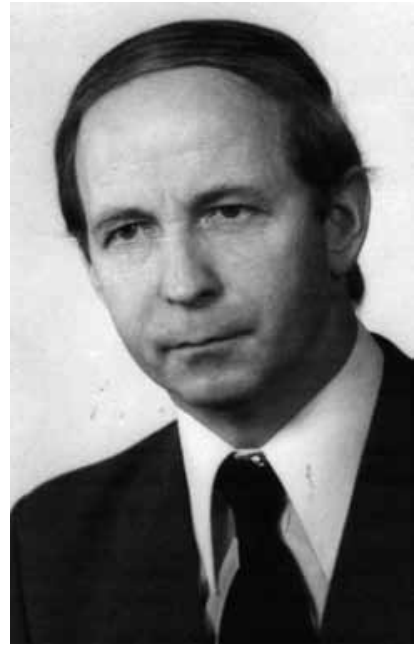

Następcą Bernarda Olejniczaka na stanowisku dyrektora Biblioteki PTPN został 16 stycznia 1980 roku Ryszard Marciniak. Urodził się 19 lutego 1939 roku w Krotoszynie. W latach 1957-1962 studiował historię na Uniwersytecie im. Adama Mickiewicza w Poznaniu (UAM). W 1962 roku obronił pracę magisterską Ustrój polityczny zwiazku obodryckiego do połowy XI wie$k u$, napisaną pod kierunkiem prof. Gerarda Labudy. Po studiach pracował jako nauczyciel historii i przysposobienia wojskowego $\mathrm{w}$ liceum ogólnokształcącym w Goleniowie. Od 1963 roku uczył matematyki i języka polskiego w Szkole Podstawowej nr 39 w Poznaniu.

Chłopskich i tajnego nauczania (rkp. 2085); wspomnienia z lat 1949-1956 dot. pracy w Bibliotece Raczyńskich w Poznaniu oraz działalności w SBP (rkp. 2086); wspomnienia z lat 1957-1962 pt. Moja dyrektura dot. pracy na stanowisku dyrektora Biblioteki Raczyńskich w Poznaniu (rkp. 2087); przypisy do wspomnień z okresu pracy w Bibliotece Raczyńskich w latach 1949-1962 (rkp. 2088); aneksy do wspomnień z okresu pracy w Bibliotece Raczyńskich w latach 1949-1962, zawierające m.in. programy szkoleń bibliotekarskich, projekty dokumentów, plany pracy, sprawozdania z inspekcji filii bibliotecznych, sprawozdania, korespondencję, zarządzenia, opinie, schematy organizacyjne, memoriały i notatki (rkp. 2089); spis skrótów i indeksy do wspomnień z lat 1949-1962 (rkp. 2090); wspomnienia z okresu nauki w gimnazjum, służby wojskowej (1937-1938) oraz studiów uniwersyteckich w latach 1938-1939 i 1945-1948 (rkp. 2091); materiały biograficzne i dzienniki ojca Bolesława Olejniczka (rkp. 2092); życiorysy Bernarda Olejniczaka i wykazy jego publikacji (rkp. 2093); jego teksty satyryczne (fraszki, satyry i wierszowane życzenia) oraz tłumaczenia z języka francuskiego i niemieckiego na polski (rkp. 2094); Myśli własne i cudze autorstwa Bernarda Olejniczaka (rkp. 2095); Tom wspomnień w pieśniach bez nut, których nie potrafitem zapisać autorstwa Bernarda Olejniczaka (rkp. 2096); jego tekst pt. Słownictwo mieszkańców Kościana w międzywojennym dwudziestoleciu (rkp. 2097); recenzje publikacji dot. bibliotekoznawstwa, filologii romańskiej i historii (rkp. 2098); poprawki i uzupełnienia do Nowej księgi przysłów i wyrażeń przysłowiowych polskich (rkp. 2099); materiały do prac naukowych z lat 1945-1987 (rkp. 2100); wspomnienia z okresu pracy na stanowisku dyrektora Biblioteki PTPN, tj. z lat 1963-1979 (rkp. 2101-2104); przypisy i uzupełnienia (rkp. 2105), aneksy (rkp. 2106) oraz indeksy do tychże wspomnień (rkp. 2107); listy Józefa Dużyka do Bernarda Olejniczaka z lat 1966-1982 (rkp. 2116) oraz z lat 1983-2000 (rkp. 2117); kopie listów Bernarda Olejniczka do Józefa Dużyka z lat 1965-2000 (rkp. 2118); wycinki artykułów Józefa Dużyka z lat 1980-2000 (rkp. 2119) - na podstawie Inwentarza rękopisów Biblioteki... 
W 1965 roku (za czasów dyrekcji doc. Stefana Weymana) został zatrudniony w Bibliotece Kórnickiej PAN. Przez 15 lat pracy przeszedł tam wszystkie szczeble kariery bibliotekarskiej. Do 1975 roku pracował w Dziale Zbiorów Specjalnych przy inwentaryzacji i katalogowaniu rękopisów. Po odejściu w 1976 roku Stefana Weymana dyrektorem Biblioteki Kórnickiej został Marceli Kosman, który na swego zastępcę do spraw bibliotecznych wybrał właśnie Ryszarda Marciniaka. Funkcję wicedyrektora pełnił on od 1 września 1976 roku do końca 1979 roku. Sprawował nadzór nad Działem Opracowania Nowych Druków, Działem Udostępniania i Działem Zbiorów Specjalnych. W 1967 roku obronił pracę doktorską Dobra kapituty kamieńskiej do połowy XV wieku, napisaną pod kierunkiem prof. Gerarda Labudy. W 1968 roku zdał egzamin na bibliotekarza dyplomowanego.

W styczniu 1980 roku objął stanowisko dyrektora Biblioteki PTPN, które piastował aż do śmierci w styczniu 2009 roku. W 1986 roku rozpoczął unowocześnianie biblioteki, pozyskując pierwszy komputer. Wdrożył też w niej system Horizon. Wprowadził ją do Poznańskiej Fundacji Bibliotek Naukowych, której był współinicjatorem. Po wyjściu Biblioteki PTPN spod kurateli PAN, od 1991 roku, co roku występował dla niej o grant do Komitetu Badań Naukowych (KBN). W 1991 roku ukazał się katalog XVI-wiecznych poloników (starodruków) ze zbiorów Biblioteki PTPN, przygotowany przez Elżbietę Stelmaszczyk pod jego kierunkiem i z indeksem jego autorstwa. Doprowadził do finału publikację Inwentarza rękopisów Poznańskiego Towarzystwa Przyjaciót Nauk (sygn. 1-1590) (Warszawa 2008), nad którym pracę rozpoczął Bernard Olejniczak. Redagował i współtworzył Bibliografię historii Wielkopolski (za lata 1939-2000).

Kierowanie Biblioteką PTPN skłoniło Ryszarda Marciniaka do działalności w samym towarzystwie. Od 1976 roku był członkiem Komisji Historycznej PTPN, a od 1987 roku członkiem Wydziału II PTPN. Pełnił funkcję zastępcy sekretarza generalnego (1990-1999), skarbnika (1996-2005) i sekretarza Wydziału II (2005-2007). Opracował monografię Prezesi Poznańskiego Towarzystwa Przyjaciót Nauk (Poznań 1998). W 2007 roku PTPN nadało mu godność członka honorowego.

9 listopada 1981 roku uzyskał stopień doktora habilitowanego nauk humanistycznych w zakresie historii Polski na podstawie rozprawy Acta Tomiciana w kulturze politycznej Polski okresu Odrodzenia. Od 1 marca 1984 roku był docentem w PAN. Od 1988 roku prowadził zajęcia ze studentami bibliotekoznawstwa, a następnie filologii polskiej na Wydziale Filologii Polskiej i Klasycznej UAM w Poznaniu. W 1991 roku został mianowany profesorem nadzwyczajnym w Instytucie Filologii Polskiej UAM w Poznaniu. 20 czerwca 2003 roku uzyskał tytuł profesora (belwederskiego). 
Ryszard Marciniak był członkiem rad naukowych Biblioteki Uniwersyteckiej i Biblioteki Kórnickiej. Od 1987 roku był członkiem redakcji „Przeglądu Wielkopolskiego", a od 1991 roku komitetu redakcyjnego „Kroniki Wielkopolski". Jego zainteresowania naukowe obejmowały: historię Pomorza w średniowieczu, publikacje źródłowe, dzieje książki i księgozbiorów, dzieje Wielkopolski w XIX i XX wieku, dzieje nauki w Wielkim Księstwie Poznańskim. Opublikował 114 pozycji: monografii, artykułów naukowych i popularnonaukowych, edycji źródłowych. Napisał też wiele recenzji prac doktorskich i habilitacyjnych oraz ponad 200 recenzji wydawniczych.

W 1999 roku otrzymał Medal Komisji Edukacji Narodowej oraz medal w dowód uznania za zasługi dla bibliotekarstwa polskiego, przyznany przez Zarząd Główny SBP, a w 2002 roku nagrodę im. Andrzeja Wojtkowskiego ufundowaną przez marszałka województwa poznańskiego. Pośmiertnie został odznaczony Krzyżem Kawalerskim Orderu Odrodzenia Polski przez Prezydenta RP. Zmarł 10 stycznia 2009 roku w Poznaniu ${ }^{24}$.

Materiały archiwalne Ryszarda Marciniaka trafiły do zbioru rękopisów Biblioteki PTPN oraz do PAN Archiwum w Warszawie Oddział w Poznaniu. Nie zostały jeszcze opracowane. W Bibliotece PTPN znajdują się między innymi jego artykuły (w tym wydany pośmiertnie Pomorski bibliofil Walenty Wolski z Niestępowa (1750-1829) i losy jego zbiorów w Wielkopolsce); materiały warsztatowe do wykładów na UAM w Poznaniu; recenzje; opinie i recenzje prac doktorskich i habilitacyjnych; korespondencja z instytucjami; notatniki i notesy; dyplomy i podziękowania; fotografie rodzinne oraz książki z dedykacjami autorów ${ }^{25}$.

Od 2009 roku spuścizna Ryszarda Marciniaka jest systematycznie przekazywana ( $w$ darze) przez rodzinę do PAN Archiwum w Warszawie Oddział w Poznaniu. Również PTPN w 2009 roku przekazało (jako dar) część jego materiałów. Do końca 2010 roku do archiwum trafiło około dwóch metrów bieżących akt. Spuścizna ta nosi sygnaturę P.III-144. W 2011 roku sporządzono jej wstępny spis. Ważną część spuścizny Ryszarda Marciniaka w zbiorach PAN Archiwum w Warszawie Oddział w Poznaniu stanowią materiały twórczości naukowejej. Wśród

${ }^{24}$ A. Mężyński, J. Wiesiołowski, Ryszard Marciniak (1939-2009) - bibliotekarz i historyk doskonały, "Roczniki Biblioteczne” 54, 2010, s. 173-191; J. Pietrowicz, Ryszard Marciniak - historyk, bibliotekarz, redaktor "Kroniki Wielkopolski”, „Kronika Wielkopolski” 2010, nr 4, s. 81-85.

25 Materiały Ryszarda Marciniaka (bez sygn.), Biblioteka PTPN, Dział Zbiorów Specjalnych.

${ }^{26}$ Są to m.in.: rękopis pracy magisterskiej pt. Ustrój polityczny Zwiąku Obodryckiego do połowy XI wieku, tekst rozprawy doktorskiej pt. Dobra Kapituły Kamieńskiej do połowy XV wieku oraz konspekt pracy habilitacyjnej. Zachowały się również teksty 
materiałów działalności naukowej znajdują się plany pracy, sprawozdania i korespondencja dotycząca redakcji Acta Tomiciana. Do materiałów działalności w Bibliotece Kórnickiej należą między innymi katalogi i spisy rękopisów. Materiały działalności w Radzie Naukowej Biblioteki Kórnickiej to: korespondencja, plany pracy i sprawozdania roczne. Wśród materiałów działalności w PTPN i Bibliotece PTPN znajdują się: korespondencja z lat 1983-2008; inwentarze; protokoły z posiedzeń PTPN; notatki i tabele dotyczące związków PTPN z polskimi ośrodkami naukowymi; notatki i korespondencja dotyczące inkunabułów w zbiorach biblioteki; wnioski o finansowanie projektów badawczych KBN; plany, wnioski i raporty dotyczące Bibliografii historii Wielkopolski. Do materiałów działalności na UAM i w Radzie Naukowej Biblioteki Uniwersyteckiej w Poznaniu należą: korespondencja z lat 2003-2005, sprawozdania, zdjęcia magazynów bibliotecznych. Materiały działalności dydaktycznej to między innymi założenia ogólne, zagadnienia i pytania egzaminacyjne, korespondencja, plany zajęć, regulamin studiów, sprawozdania dotyczące studiów bibliotekoznawstwa na UAM w Poznaniu; program zajęć i notatki do studium podyplomowego edytorstwa na UAM w Poznaniu z lat 2000/2001 i 2001/2002. Zachowały się też oceny prac magisterskich i recenzje prac doktorskich. Są też materiały działalności w Towarzystwie Miłośników Krotoszyna. Cenna jest korespondencja wpływająca i wychodząca Ryszarda Marciniaka z lat 1967-2008. Materiały biograficzne obejmują między innymi: materiały do wniosku o nadanie tytułu naukowego profesora (oceny dorobku naukowego, życiorys, kwestionariusz

jego artykułów, m.in.: Biblioteka biskupa Jana Lubrańskiego; Wydziat Lekarski Poznańskiego Towarzystwa Przyjaciót Nauk (zarys dziejów); Towarzystwo Zbieraczów Starożytności Krajowych w Szamotułach (1840-1846). Ponadto znajdują się tam hasła do Wielkopolskiego słownika biograficznego. Liczne są też materiały warsztatowe, wśród których na czoło wysuwają się regesty dokumentów, notatki i bibliografie do Acta Tomiciana. Oprócz nich zachowały się m.in.: katalogi kartkowe z bibliografią dot. dziejów Pomorza Zachodniego w średniowieczu; kserokopie artykułów, wycinki z gazet i notatki dot. Towarzystwa Zbieraczów Starożytności Krajowych w Szamotułach; wypisy i notatki dot. ks. Stanisława Kozierowskiego; materiały warsztatowe dot. statutów Bledzewa i dokumentów cechowych; notatki i wypisy z tzw. Teki Górskiego; notatki, wypisy, kserokopie (pieczęci, herbów, artykułów itp.) dot. herbu Wielkopolski; notatki i wypisy do Bibliografii historii Wielkopolski; notatki i wypisy dot. historiografii zachodniopomorskiej w XVI-XVIII wieku; notatki do Słownika historyczno-geograficznego województwa poznańskiego w średniowieczu; wycinki prasowe dot. księgoznawstwa; notatki dot. historii książek i księgozbiorów w Wielkopolsce; notatki, wypisy, kserokopie materiałów źródłowych dot. Walentego Wolskiego; materiały warsztatowe dot. księgozbiorów Działyńskich; notatki, wypisy i wycinki z gazet dot. Krotoszyna i dekanatu krotoszyńskiego. 
osobowy, spisy prac i publikacji, korespondencja); korespondencję i listę gości na obchody jubileuszu 60-lecia urodzin. Wśród materiałów osób obcych znajdują się między innymi teksty: Biblioteki Naukowe w Generalnym Gubernatorstwie w latach 1939-1945. Wybór źródet oraz Stan obecny i koncepcja reorganizacji sieci filii bibliotecznych Biblioteki Raczyńskich w Poznaniu²7.

Zaprezentowane spuścizny stanowią ważne źródło dla uczonych i badaczy z różnych dziedzin. Znajdą tu coś dla siebie bibliotekoznawcy, historycy i językoznawcy. Archiwalia te są również odzwierciedleniem dorobku naukowego i zawodowych osiągnięć konserwatorów zbiorów, kierowników i dyrektorów Biblioteki Poznańskiego Towarzystwa Przyjaciół Nauk. Pozwalają też zrozumieć, jak funkcjonuje typowa biblioteka naukowa.

\title{
MICHAє BOKSA
}

\section{The legacy of book conservators, heads of departments of conservation and the directors of the Library of the Poznań Society of the Friends of Sciences}

\begin{abstract}
Aвstract. The present article provides a number of profiles of book conservators, heads of the departments of book conservation and directors of the Library of the Poznan Society of the Friends of Sciences (Polish: PTPN) and their legacy remained in the form of available archival material. From its onset, the PTPN Library has been collecting manuscripts and bequests of prominent people that included books and other material, including bequests of those who had been heading the institution. The archival material that belonged to the latter group has been also collected by other libraries and archives with which they were in close contact. The legacy of Ludwika Dobrzyńska-Rybicka and Ryszard Marciniak has been thus split between the PTPN Library and the Library of the Poznan branch of the Polish Academy of Science. The bulk of the archival material bequeathed by Bolesław Erzepki has been located in the Special Collection Division of the Raczyński Municipal Library in Poznań. Residual relevant archival material can be also found in the Archives of the Adam Mickiewicz University in Poznań (L. Dobrzyńska-Rybicka) and in the Archives of Poznań University Library (L. Dobrzyńska-Rybicka, Jan Baumgart, Aniela Koehlerówna).
\end{abstract}

KEY wORDs: legacy, library, archives.

${ }^{27}$ Materiały Ryszarda Marciniaka (P.III-144); Spis materiałów Ryszarda Marciniaka (sygn. P.III-144), PAN Archiwum w Warszawie Oddział w Poznaniu. 
